\title{
PENGARUH SELF EFFICACY DAN PENGAMBILAN KEPUTUSAN TERHADAP KINERJA KEPALA MADRASAH TSANAWIYAH (MTS) SE-KABUPATEN TANAH DATAR
}

\author{
Helmizuldi \\ Kepala Seksi Bimas Islam Kementrian Agama Kabupaten Tanah Datar \\ e-mail: helmizuldi@gmail.com
}

\begin{abstract}
: his study was aimed at revealing the influence of self-efficacy and decision making on the headmasters' job performance of Tsanawiyah Secondary School (MTs) In Tanah Datar. The sample of this study were the headmasters of Tsanawiyah Secondary School (MTs) in Tanah Datar consisted of 32 headmasters which were selected from 48 headmasters by using stratified proportional random sampling technique. The data were collected by using questionnaire. The findings revealed that (1) self efficacy significantly influenced 25,3\% toward headmasters' job performance; (2) decision making significantly influenced 27,4\% toward headmasters' job performance; and (3) self efficacy and decision making significantly influenced $38.8 \%$ toward headmasters' job performance. It can be concluded that self efficacy and decision making were two important factors that influenced headmasters' job performance of Tsanawiyah Secondary School (MTs) in Tanah Datar.
\end{abstract}

Keywords: Self-Efficacy, Decision Making, Headmasters'Job Performance, Tsanawiyah Secondary School

\section{PENDAHULUAN}

Madrasah merupakan organisasi yang kompleks dan unik. Kompleks karena dalam operasionalnya madrasah dibangun oleh berbagai unsur yang satu sama lain saling berhubungan dan saling menentukan. Madrasah sebagai suatu lembaga yang berbentuk organisasi yang di dalamnya terhimpun kelompok-kelompok manusia yang secara perorangan maupun kelompok melakukan hubungan kerja sama untuk mencapai tujuan pendidikan. Kelompok manusia yang dimaksud adalah terdiri dari Kepala Madrasah, guru-guru, tenaga administratif, dan kelompok siswa. Organisasi ini unik, karena madrasah merupakan organisasi yang khas menyelenggarakan proses perubahan perilaku dan proses pembudayaan manusia yang tidak dimiliki oleh organisasi manapun. Dikarenakan kompleks dan rumitnya tersebut, maka dalam pelaksanaan pendidikan di Madrasah memerlukan pengaturan, pengarahan dan koordinasi yang tinggi dari seorang Kepala Madrasah. 
Kepala Madrasah menentukan maju mundurnya tujuan pendidikan yang akan dicapai. Jika Madrasah dipimpin oleh pemimpin yang kompeten dan profesional, maka Madrasah akan maju. Sebaliknya, jika Madrasah dipimpin oleh pemimpin yang tidak berkualitas dan tidak profesional maka Madrasah akan kalah dalam persaingan yang kian bertambah ketat antar lembaga pendidikan.

Sesuai dengan Undang-Undang Sistem Pendidikan Nasional dan Peraturan Pemerintah, Madrasah sudah seharusnya memerlukan kinerja yang efektif dan efisien. Di sisi lain, perkembangan ilmu pengetahuan, teknologi, seni, dan budaya cenderung bergerak maju semakin pesat, sehingga menuntut Kepala Madrasah lebih inovatif dan profesional. Setiap Kepala Madrasah dihadapkan pada tantangan untuk melakukan pengembangan pendidikan Madrasah secara terarah, terencana, dan berkesinambungan untuk meningkatkan kualitas pendidikan. Dalam hal ini, diperlukan peningkatan profesionalisme manajemen Madrasah secara profesional, menuntut peran aktif dan kinerja profesional Kepala Madrasah. Kinerja Kepala Madrasah memerlukan berbagai kompetensi seperti kompetensi manajerial, kompetensi teknis, dan kompetensi sosial. Purwanto (2004: 62) mengungkapkan bahwa tugas seorang pemimpin lembaga pendidikan, selain harus memenuhi kebutuhan kelompok juga harus dapat mempengaruhi kelompok sedemikian rupa sehingga apa yang dirasakan sebagai kebutuhan benar-benar bersifat realistis, yaitu sesuai dengan kenyataan, idaman semua kelompok baik yang buruk maupun yang baik atau yang hanya sebatas khayalan belaka harus dirombak oleh pemimpin ke dalam tujuan yang realistis.

Dalam melaksanakan tugas pokoknya sebagai seorang Kepala Madrasah harus mampu menciptakan kerja tim yang baik di lingkungan Madrasah yang dipimpinnya. Pengambilan keputusan yang baik sangat menentukan timbulnya motivasi kerja bagi setiap komponen yang ada di Madrasah tersebut. Pengambilan keputusan yang baik akan membentuk program kerja yang solid untuk mewujudkan tujuan yang akan dicapai dan akan meningkatkan motivasi kerja bagi setiap komponen-komponen yang ada di Madrasah tersebut.

Dalam memimpin suatu organisasi atau lembaga pendidikan, seorang pimpinan dituntut bisa mengambil suatu keputusan yang tepat. Keputusan yang diambil harus sesuai dengan tuntutan organisasi, untuk itu kepala Madrasah membutuhkan efektifitas diri (self-efficacy) yang baik agar mampu mengambil keputusan dengan baik. Selfefficacy secara umum adalah keseluruhan pandangan seseorang tentang diri sendiri 
mampu berkinerja secara efektif dalam berbagai macam situasi dalam proses kegiatan organisasi atau dalam mengambil keputusan, hal ini akan meningkatkan kinerja Kepala Madrasah akan tugas dan tanggung jawab yang dibebankan kepadanya. Dengan adanya self-efficacy, Kepala Madrasah tahu benar mengenai apa yang harus dikerjakan berkaitan dengan pencapaian tujuan Madrasah tersebut.

\section{PENGERTIAN KINERJA KEPALA MADRASAH}

Istilah kinerja berasal dari kata job performance atau actual performance (prestasi kerja atau prestasi sesungguhnya yang dicapai oleh seseorang). Pengertian kinerja (prestasi kerja) adalah "hasil kerja secara kualitas dan kuantitas yang dicapai oleh seseorang dalam melaksanakan tugasnya dengan tanggung jawab yang diberikan kepadanya” (Mangkunegara, 2004: 67).

Kinerja kepala madrasah adalah kemampuan untuk melaksanakan pekerjaan atau tugas dan fungsi yang dimiliki Kepala Madrasah dalam menyelesaikan suatu pekerjaan di sekolah yang dipimpin. Dilihat dari ukuran keberhasilan sekolah, kinerja Kepala Madrasah dapat ditampilkan dalam keberhasilan yang berkenaan dengan pengelolaan sekolah, kegiatan pembelajaran, ketenagaan, sarana prasarana, keuangan, lingkungan sekolah, dan hubungan sekolah dengan masyarakat.

Faktor-faktor yang mempengaruhi kinerja Kepala Madrasah adalah faktor kemampuan (ability) dan faktor motivasi (motivation). Hal ini sesuai dengan pendapat Keith Davis dalam Mangkunegara (2004: 67) yang merumuskan bahwa kinerja seseorang dipengaruhi oleh motivasi dari dalam diri seseorang, kemampuan yang dimiliki seseorang serta situasi lingkungan kerja, organisasi, sumberdaya, kejelasan tugas, dan sarana. Kinerja Kepala Madrasah dapat dinilai dari kinerja tugas atau kinerja teknis yang ditandai dengan kemampuan menjalankan tugas pokok, menjalankan tugas diluar tugas pokok, berkomunikasi secara tulis dan lisan, serta kemampuan manajerial atau administrasi. Selain itu, "kinerja Kepala Madrasah dapat dinilai dari kinerja kontekstual atau kinerja interpersonal yang mencakup kemampuan berusaha, kedisiplinan, dukungan terhadap kinerja teman atau kelompok, serta kemampuan supervisi atau memimpin" (Hadi, 2008: 20). Jadi, kinerja Kepala Madrasah adalah hasil kerja yang dicapai oleh Kepala Madrasah dalam melaksanakan tugas pokok, fungsi dan tanggungjawabnya dalam memimpin dan mengelola sekolah. Hasil kerja tersebut merupakan refleksi dari kompetensi yang dimilikinya. Kinerja Kepala Madrasah 
terdiri dari dimensi: a) kemampuan menyusun program sekolah, b) kemampuan menyusun organisasi kepegawaian sekolah, c) kemampuan menggerakkan staf (guru dan karyawan), dan d) mengoptimalkan kemampuan sumber daya sekolah.

\section{SELF- EFFICACY (EFEKTIVITAS DIRI)}

Salah satu faktor internal individu yang dapat mempengaruhi kinerja adalah self-efficacy. Menurut Krietner and Kinicki (2007: 144) "self-efficacy is a person's belief about his or her chances of sucesfully accomplishing a specific task" (Kemampuan seseorang untuk dapat memanfaatkan peluang yang dimilikinya dan berhasil mencapai tugas tertentu sangat dipengaruhi oleh tingkat self-efficacy yang dimilikinya). Menurut Quick dan Nelson (2009: 87) bahwa "self-efficacy generall self-efficacy is a person's overall view of himself/herself as being able to perfom effectivily in a wide variety of situations" (secara umum keseluruhan pandangan seseorang tentang diri sendiri mampu berkinerja secara efektif dalam berbagai macam situasi).

Self-efficacy mengacu pada estimasi kemampuan individu sendiri untuk melakukan tugas spesifik dalam mengahadapi situasi. Karyawan tertentu yang yang dianggap mempunyai kemampuan untuk melakukan tugas, mereka yang tinggi efektivitas dirinya. Kepala Madrasah dengan efektivitas diri tinggi percaya bahwa; (1) merasa memiliki kemampuan yang dibutuhkan, (2) mereka mampu melakukan usaha yang diperlukan, dan (3) apabila di kirim untuk kegiatan keluar mereka mempunyai kinerja yang bagus di levelnya. Jika karyawan mempunyai efektivitas diri rendah mereka percaya bahwa tak peduli seberapa keras mereka mencoba, sesuatu akan terjadi untuk mencegah mereka dari mencapai tingkat yag diinginkan.

Self-efficacy secara umum dapat dibedakan atas dua kelompok, yaitu selfefficacy diri khusus dan umum. Self-efficacy khusus, yang mengikuti konsep Bandura dan banyak diakui oleh hampir semua ilmuwan tentang kemampuan ini dan seluruh bidang psikologi. Namun pada tahun-tahun belakangan ini, self-efficacy umum telah digunakan sebagai dimensi lain self-efficacy oleh beberapa peneliti tentang kemampuan. Self-efficacy umum, yang merujuk pada keyakinan orang dalam keberhasilan mencapai tugas melalui berbagai situasi prestasi.Kemampuan umum ini cukup berbeda dari gambaran Bandura tentang self-eficacy, khususnya versi selfefficacy tugas khusus yang diterima mirip situasi (Luthans, 2008). Self-efficacy khusus sangat beragam tergantung pada tugas khusus dan dioleh secara kognitif oleh 
individu sebelum usaha itu dikembangkan.

Berdasarkan uraian di atas, maka yang dimaksud dengan self-efficacy adalah evaluasi seseorang terhadap dirinya sendiri atas kemampuan atau kompetensinya untuk melakukan sebuah tugas, mencapai tujuan, dan menggerakkan motivasi yang diperlukan untuk keberhasilan dalam melaksanakan tugas diukur dengan indikator (1) keyakinan diri mampu mengerjakan tugas, (2) kemantapan menghadapi tugas dan (3) kesanggupan menyelesaikan tugas.

\section{PENGAMBILAN KEPUTUSAN}

Menurut Siagian (2002) pengambilan keputusan adalah suatu pendekatan yang sistematis terhadap perhitungan alternatif yang dihadapi dan mengambil tindakan yang menurut perhitungan merupakan tindakan yang paling tepat. Menurut Stoner (1982) pengambilan keputusan adalah proses yang digunakan untuk memilih suatu tindakan sebagai cara pemecahan masalah. Faktor yang mempengaruhi pengambilan keputusan yaitu (1) informasi yang diketahui perihal permasalahan yang dihadapi; (2) tingkat pendidikan; (3) personality; (4) coping, dalam hal ini dapat berupa pengalaman hidup yang terkait dengan permasalahan (proses adaptasi); dan (5) culture (Khasanah Ilmu, 2015).

\section{METODE PENELITIAN}

Populasi dalam penelitian ini adalah 48 orang Kepala Madrasah Tsanawiyah (MTs) se-Kabupaten Tanah Datar yang terdiri dari 31 orang kepala Madrasah Tsanawiyah Swasta (MTsS) dan 17 orang kepala Madarasah Tsanawiyah Negeri (MTsN). Sampel dalam penelitian ini diambil dengan menggunakan rumus Cochran dan teknik stratified proportional random sampling. Jumlah sampel penelitian ini sebanyak 32 orang Kepala Madrasah Tsanawiyah (MTs) se-Kabupaten Tanah Datar. Metode Pengumpulan data dilakukan melalui angket dengan menggunakan skala likert. Data penelitian dianalisis dengan menggunakan teknik korelasi dan regresi. Analisis data dilakukan dengan menggunakan bantuan program komputer SPSS versi 17.

\section{HASIL PENELITIAN}

Data variabel kinerja Kepala Madrasah Tsanawiyah (MTs) se-Kabupaten Tanah Datar diperoleh dari 27 butir pernyataan. Idealnya skor variabel kinerja Kepala Madrasah Tsanawiyah (MTs) se-Kabupaten Tanah Datar adalah 135, skor variabel kinerja Kepala Madrasah Tsanawiyah (MTs) se-Kabupaten Tanah Datar menyebar antara (terendah) 88 dan 106 (tertinggi). Selanjutnya diperoleh rata-rata skor variabel 
kinerja Kepala Madrasah Tsanawiyah (MTs) se-Kabupaten Tanah Datar (mean) sebesar 95,21, skor tengah variabel kinerja Kepala Madrasah Tsanawiyah (MTs) se-Kabupaten Tanah Datar (median) sebesar 95.00, skor yang banyak muncul variabel kinerja Kepala Madrasah Tsanawiyah (MTs) se-Kabupaten Tanah Datar (mode) 97 dan simpangan baku variabel kinerja Kepala Madrasah Tsanawiyah (MTs) se-Kabupaten Tanah Datar (standard deviation) 4.475.

Selanjutnya tingkat pencapaian responden pada variabel kinerja Kepala Madrasah Tsanawiyah (MTs) se-Kabupaten Tanah Datar diperoleh 70,53\%. Capaian ini termasuk kategori Cukup. Dari data ini dapat dikatakan bahwa kinerja Kepala Madrasah Tsanawiyah (MTs) se-Kabupaten Tanah Datar pada umumnya berada dalam kategori Cukup.

Data variabel self-efficacy Kepala Madrasah Tsanawiyah (MTs) se-Kabupaten Tanah Datar diperoleh dari 28 butir pernyataan. Idealnya skor variabel selfefficacy Kepala Madrasah Tsanawiyah (MTs) se-Kabupaten Tanah Datar adalah 140, skor self-efficacy Kepala Madrasah Tsanawiyah (MTs) se-Kabupaten Tanah Datar menyebar antara 84 (terendah) dan 106 (tertinggi). Selanjutnya diperoleh skor rata-rata selfefficacy Kepala Madrasah Tsanawiyah (MTs) se-Kabupaten Tanah Datar (mean) sebesar
93,31, skor tengah self-efficacy Kepala Madrasah Tsanawiyah (MTs) se-Kabupaten Tanah Datar (median) sebesar 93,00, skor yang banyak muncul self-efficacy Kepala Madrasah Tsanawiyah (MTs) se-Kabupaten Tanah Datar (mode) 85 dan simpangan baku self-efficacy Kepala Madrasah Tsanawiyah (MTs) se-Kabupaten Tanah Datar (standard deviation) 6,698. Tingkat pencapaian responden pada variabel self-efficacy Kepala Madrasah Tsanawiyah (MTs) se-Kabupaten Tanah Datar diperoleh 66,65\%. Capaian ini termasuk kategori Cukup. Dari data ini dapat dikatakan bahwa Self Efficacy Kepala Madrasah Tsanawiyah (MTs) se-Kabupaten Tanah Datar pada umumnya berada dalam kategori Cukup.

Data variabel pengambilan keputusan Kepala Madrasah Tsanawiyah (MTs) seKabupaten Tanah Datar diperoleh dari 28 butir pernyataan. Idealnya skor variabel pengambilan keputusan Kepala Madrasah Tsanawiyah (MTs) se-Kabupaten Tanah Datar adalah 140, skor variabel pengambilan Keputusan Kepala Madrasah Tsanawiyah (MTs) se-Kabupaten Tanah Datar menyebar antara 94 (terendah) dan 116 (tertinggi). Selanjutnya diperoleh skor rata-rata Pengambilan Keputusan Kepala Madrasah Tsanawiyah (MTs) se-Kabupaten Tanah Datar (mean) sebesar 108,90 skor tengah pengambilan keputusan Kepala Madrasah 
Tsanawiyah (MTs) se-Kabupaten Tanah Datar (median) sebesar 105,00 skor yang banyak muncul pengambilan keputusan Kepala Madrasah Tsanawiyah (MTs) seKabupaten Tanah Datar (mode) 95 dan simpangan baku pengambilan keputusan Kepala Madrasah Tsanawiyah (MTs) seKabupaten Tanah Datar (standard deviation) 6,821 . Tingkat pencapaian responden pada variabel pengambilan keputusan Kepala Madrasah Tsanawiyah (MTs) se-Kabupaten Tanah Datar diperoleh 74,93\%. Capaian ini termasuk kategori Cukup. Dari data ini dapat dikatakan bahwa Pengambilan Keputusan Kepala Madrasah Tsanawiyah (MTs) se-Kabupaten Tanah Datar pada umumnya berada dalam kategori Cukup.

\section{UJI HIPOTESIS PERTAMA}

Dalam penelitian ini hipotesis yang pertama diajukan adalah self-efficacy berpengaruh terhadap Kinerja kepala Madrasah. Dasar pengambilan keputusan adalah $\mathrm{H}_{\mathrm{O}}$ diterima jika nilai signifikasi $>$ Alpha 0,05 atau $\mathrm{H}_{1}$ diterima jika nilai signifikasi < Alpha 0,05. Angka koofisien variabel Self Efficacy terhadap variabel kinerja Kepala Madrasah (ry.1) sebesar 0.503. Angka korelasi ini menunjukkan bahwa terdapat pengaruh yang positif dan cukup kuat antara self-efficacy terhadap kinerja kepala Madrasah. Angka koofisien determinasi sebesar 0.253 dengan signifikasi sebesar 0.000 , sesuai dengan pengambilan keputusan di atas, maka $\mathrm{H}_{\mathrm{O}}$ di tolak dan $\mathrm{H}_{1}$ diterima. Ini berarti terdapat pengaruh yang signifikan antara self-efficacy terhadap kinerja Kepala Madrasah sebesar 25,3 \%. Dengan kata lain, 25,3\% kinerja Kepala Madrasah Tsanawiyah (MTs) se-Kabupaten Tanah Datar dipengaruhi oleh self-efficacy Kepala Madrasah Tsanawiyah (MTs) se-Kabupaten Tanah Datar.

\section{UJI HIPOTESIS KEDUA}

Hipotesis kedua yang diajukan dalam penelitian ini adalah pengambilan keputusan berpengaruh terhadap kinerja Kepala Madrasah Tsanawiyah (MTs) se-Kabupaten Tanah Datar. Dasar pengambilan keputusan adalah $\mathrm{H}_{\mathrm{O}}$ diterima jika nilai signifikasi $>$ Alpha 0,05 atau $\mathrm{H}_{1}$ diterima jika nilai signifikasi < Alpha 0,05. Angka koefisien variabel pengambilan keputusan terhadap variabel kinerja Kepala Madrasah Tsanawiyah (MTs) seKabupaten Tanah Datar (ry2) sebesar 0.523 . Angka korelasi ini menunjukkan bahwa pengaruh pengambilan keputusan terhadap variabel kinerja Kepala Madrasah berkorelasi positif. Ini berarti terdapat pengaruh yang positif dan signifikan antara pengambilan keputusan terhadap kinerja Kepala Madrasah Tsanawiyah (MTs) se- 
Kabupaten Tanah Datar dengan kontribusi sebesar $27,4 \%$.

\section{UJI HIPOTESIS KETIGA}

Dalam penelitian ini hipotesis ketiga yang diajukan adalah self-efficacy serta pengambilan keputusan secara bersamasama berpengaruh terhadap kinerja Kepala Madrasah Tsanawiyah (MTs) se-Kabupaten Tanah Datar. Dasar pengambilan keputusan adalah $\mathrm{H}_{\mathrm{O}}$ diterima jika nilai signifikasi $>$ Alpha 0,05 atau $\mathrm{H}_{1}$ diterima jika nilai signifikasi < Alpha 0,05. Angka koefisien korelasi ganda antara self-efficacy serta pengambilan keputusan secara bersamasama terhadap variabel kinerja Kepala Madrasah $\left(\mathrm{ry}_{12}\right.$ ) sebesar 0.623. Ini berarti terdapat pengaruh yang signifikan antara self-efficacy serta pengambilan keputusan secara bersama-sama terhadap variabel kinerja Kepala Madrasah Tsanawiyah (MTs) se-Kabupaten Tanah Datar dengan kontribusi sebesar 38,8\%.

\section{PEMBAHASAN}

Setelah dilakukan pengkajian mendalam melalui proses analisis di atas, maka diyakini bahwa hipotesis penelitian yang menyatakan self-efficacy berpengaruh terhadap kinerja Kepala Madrasah Tsanawiyah (MTs) seKabupaten Tanah Datar dapat diterima dan telah teruji pada tarap kepercayaan
95\%. Selanjutnya dapat diinterprentasikan bahwa self-efficacy memiliki pengaruh dan hubungan sangat signifikan terhadap kinerja Kepala Madrasah Tsanawiyah (MTs) se-Kabupaten Tanah Datar sebesar 25,3\%. Hal ini menunjukkan bahwa 25,3\% keberhasilan kinerja Kepala Madrasah Tsanawiyah (MTs) se-Kabupaten Tanah Datar ditentukan oleh self-efficacy dari kepala Madrasah tersebut.

Pengambilan keputusan berpengaruh terhadap kinerja Kepala Madrasah Tsanawiyah (MTs) se-Kabupaten Tanah Datar tergambar bahwa terdapat pengaruh yang postif dan signifikan terhadap kinerja Kepala Madrasah Tsanawiyah (MTs) seKabupaten Tanah Datar dapat diterima dan telah teruji pada taraf kepercayaan $95 \%$. Selanjutnya dapat diinterprentasikan bahwa pengambilan keputusan memiliki pengaruh yang signifikan terhadap kinerja Kepala Madrasah Tsanawiyah (MTs) se-Kabupaten Tanah Datar sebesar 27,4 \%. Hal ini menunjukkan bahwa 27,4\% keberhasilan kinerja Kepala Madrasah Tsanawiyah (MTs) se-Kabupaten Tanah Datar ditentukan oleh pengambilan keputusan.

Self-efficacy dan pengambilan keputusan secara bersama-sama berpengaruh terhadap kinerja Kepala Madrasah Tsanawiyah (MTs) se-Kabupaten Tanah Datar, adapun pengaruh dan hubungan sebesar 38,8\%. 
Hal ini menunjukkan bahwa 38,8\% kinerja Kepala Madrasah Tsanawiyah (MTs) seKabupaten Tanah Datar dipengaruhi oleh self-efficacy dan pengambilan keputusan. Dengan kata lain secara simultan kedua faktor tersebut mempunyai pengaruh terhadap kinerja Kepala Madrasah Tsanawiyah Swasta (MTsS) se-Kabupaten Tanah Datar.

Hasil temuan dalam penelitian ini didukung oleh temuan Nur (2008) dalam penelitiannya yang mengemukakan bahwa kepemimpinan Kepala Madrasah berkontribusi secara signifikan terhadap kinerja guru SD sebesar 19,9\%, sedangkan self-efficacy berkontribusi secara signifikan terhadap kinerja guru SD sebesar 38,7\% dan kepemimpinan Kepala Madrasah dan self-efficacy secara bersama-sama berkontribusi secara signifikan terhadap kinerja guru SD sebesar 48,3\%. Selanjutnya didukung oleh temuan Asmara (2004) yang mengemukakan bahwa self-efficacy dan pengambilan keputusan berpengaruh terhadap kinerja Kepala Madrasah sebesar $26,1 \%$. Temuan ini juga mendukung bahwa kepemimpinan dapat memotivasi guru dalam bekerja.

\section{KESIMPULAN}

Self-efficacy Kepala Madrasah Tsanawiyah (MTs) Se-Kabupaten Tanah
Datar berpengaruh terhadap kinerja Kepala Madrasah Tsanawiyah (MTs) se-Kabupaten Tanah Datar. Adapun besarnya pengaruh Self Efficacy terhadap kinerja Kepala Madrasah Tsanawiyah (MTs) se-Kabupaten Tanah Datar adalah 25,3\%, korelasinya positif dan signifikan terhadap kinerja Kepala Madrasah Tsanawiyah (MTs) seKabupaten Tanah Datar. Pengambilan keputusan Kepala Madrasah Tsanawiyah berpengaruh terhadap kinerja Kepala Madrasah Tsanawiyah (MTs) Se-Kabupaten Tanah Datar. Adapun besarnya pengaruh pengambilan keputusan Kepala Madrasah Tsanawiyah terhadap kinerja Kepala Madrasah Tsanawiyah (MTs) se-Kabupaten Tanah Datar adalah 27,4\%, korelasinya positif dan signifikan terhadap kinerja Kepala Madrasah Tsanawiyah (MTs) seKabupaten Tanah Datar. Self-efficacy dan pengambilan keputusan secara bersamasama berpengaruh terhadap kinerja kepala Madrasah Tsanawiyah (MTs) se-Kabupaten Tanah Datar. Adapun besarnya pengaruh self-efficacy dan pengambilan keputusan Kepala Madrasah Tsanawiyah secara bersama-sama terhadap kinerja Kepala Madrasah Tsanawiyah (MTs) se-Kabupaten Tanah Datar adalah 38,8\%, korelasinya positif dan signifikan terhadap kinerja Kepala Madrasah Tsanawiyah (MTs) seKabupaten Tanah Datar 
IMPLIKASI HASIL PENELITIAN

Dengan melihat hasil penelitian ini, maka Kepala Madrasah Tsanawiyah (MTs) se- Kabupaten Tanah Datar harus berusaha meningkatkan self-efficacy dan pengambilan keputusannya agar kinerjanya bisa meningkat. Dengan meningkatnya kinerja Kepala Madrasah maka mutu Madrasah pun dapat meningkat.

\section{KEPUSTAKAAN ACUAN}

Asmara, Elva. (2004). Korelasi antara Self Efficacy, dan Pengambilan Keputusan dengan Kinerja Kepala Madrasah Aliyah Negeri 1 Padang. Padang: Tesis PPs UNP.

Hadi, Samsul. (2008).Konstruk Kinerja Kepala Sekolah Dasar di Daerah Istimewa Yogyakarta. Jurnal Penelitian dan Evaluasi Pendidikan. Tahun XI, No.

1. 2008, Halaman 20-37

Khasanah Ilmu. (2015). Penambilan Keputusan dalam Manajemen.

http: / Khasanah Ilmu.blogspot. com/2012/02/pengambilan-keputusandalam-manajemen.html, diakses pada Kamis 05 Februari 2015
Kreitner, Robert and Kinicki, Angola. (2007). Organizational Behavior. New York: McGraw Hill.

Luthans, Fred. (2008). Organizational Behavior, Eleventh Edition. New York: McGraw-Hill

Mangkunegara. (2004). Manajemen Sumber Daya Manusia Perusahaan. Bandung: PT. Remaja Rosdakarya.

Nur, Yurman M. (2008). Kontribusi Kepemimpinan Kepala Madrasah dan Komitmen Guru terhadap Kinerja Guru. Padang: Tesis PPs UNP.

Purwanto, M. Ngalim. (2004). Administrasi dan Supervisi Pendidikan. Bandung: PT. Remaja Rosdakarya.

Siagian, Sondang P. (2002). Menajemen Sumber Daya Manusia. Jakarta: Bumi Aksara.

Stoner, James A. F. (1982). Management. USA: Prentice Hall

Quick, James Cambell and Nelson, Debra L. (2009). Principles of Organizational Behavior: Realities and Challenges. USA: Cengage Learning South Western 